\title{
Antimicrobial Properties of Sargassum spp. (Phaeophyceae) against Selected Aquaculture pathogens
}

\author{
Jonathan Mallillin Bolaños, Francis Nuestro Baleta and Jayson Domingo Cairel \\ Institute of Fisheries, Isabela State University, San Fabian, Echague, Isabela 3309, Philippines \\ *Corresponding author
}

A B S T R A C T

The purpose of this study was to investigate the antibacterial and anti-fungal activities of four species Sargassum namely: Sargassum polycystum, Sargassum oligocystum, Sargassum crassifolium and Sargassum cristaefolium collected along the coastal areas of

Keywords

Brown seaweeds, Different extracts, Bacteria, Fungi.

\section{Article Info}

Accepted: 20 January 2017 Available Online: 10 February 2017 Diora-Zinungan Sta. Ana Cagayan, Philippines. Extracts of powdered seaweeds were prepared using sequential extraction with different organic solvents in order to increasing the polarity (Ethanol, n-hexane, dichloromethane and ethyl acetate and aqueous). Five fractions (Ethanol, n-hexane, dichloromethane ethyl acetate and aqueous) were examined for antimicrobial activity by using disc diffusion assay on thirteen (13) strains of aquaculture pathogens. The n-hexane, dichloromethane, ethyl acetate extracts displayed different antimicrobial activity against different aquaculture pathogenic bacteria and fungi whereas ethanolic extracts showed higher antimicrobial activity than aqueous extracts. The extracts of Sargassum sp. showed a significant antimicrobial activity against Grampositive and Gram-negative as well as the fungus. Among the tested brown seaweeds, Sargassum polycystum exhibited the better antimicrobial activity that has potentially used as antimicrobial agent and as natural immunostimulant with aquaculture industry for the treatment of microbial diseases and improvement of the health status of commercially important aquaculture species.

\section{Introduction}

Diseases caused by the microorganism are the major problem in aquaculture farms. However, the use of various chemotherapeutics, vaccines, immunostimulants and probiotics have been used to treat bacterial infections in fish farming but the occurrence of mutants and drug-resistant microorganisms has become a major problem (Sanil and Vijayan, 2008). Decreased efficiency and resistance of pathogen to antibiotics has needed the development of new alteration (Smith et al., 1994; Ireland et al., 1988).
Seaweeds are considered as potent source of bioactive compounds and able to produce a great variety of secondary metabolites characterized by a broad spectrum of biological activities. Compounds with cytostatic, antiviral, anthelminthic, antifungal, antibacterial activities have been detected in green, brown and red algae (Newman et al., 2003; Toney et al., 2006; Taskin et al., 2007; Salem et al., 2011; Oumaskour et al., 2012; Dashtiannasab et al., 2012; Padmakumar and Ayyakkannu, 1997). Seaweeds are naturally renewable and contain high levels of 
minerals, vitamins, essential amino acids, fatty acid, dietary fiber and carbohydrates and as long as food, agricultural fertilizers and drugs have been used (Dawczynski et al., 2007), and the context of radical scavenging properties seaweeds possess natural antioxidants such as carotenoids, pigments, polyphenols, enzymes and diverse functional polysaccharides (Vinayak et al., 2011). The use of seaweeds are inexpensive than chemicals and antibiotics and have little effects on nature, humans and fish. Fishery production of the main challenges is important bacterial infections fungal every year causing significant losses in aquaculture centers are amplified (Mahianeh et al., 2014).

The brown seaweeds like Sargassum polycystum and Sargassum tenerrimum (Kausalya and Narasimha Rao, 2015), Sargassum sp. and Esiena bicyclis (Kim and Lee, 2008), Sargassum polycystum and Padina australis (Chong et al., 2011), Sargassumlatifolium (Dashtiannasab et al., 2012), Sargassum glaucescensas (Mahianeh et al., 2014), have been studied and they showed promising antibacterial and antifungal activity. In addition, Sargassum oligocystum possess biologically active compounds that may have potential as alternative antibacterial agents, replacing commercial antibiotics and chemotherapeutants for prophyxis and therapy of bacterial fish diseases (Baleta et al., 2011).

The Sargassum (Phaeophyceae) is widely distributed in coastal throughout the Philippines, particularly the coast of Sta. Ana, Cagayan. In this study was carried out to evaluate the antimicrobial activity of the four brown seaweeds obtained from Cagayan, Isabela against eight fish pathogenic bacteria and five fungi with aim of possibly using them as antimicrobial agents and as natural immunostimulant for aquaculture.

\section{Materials and Methods}

\section{Sampling and collection site}

The seaweeds were collected by scuba diving and handpicking from the rocky substratum at depth of 1-3 $\mathrm{m}$ along the subtidal areas at Diora-Zinungan, Santa Ana (coordinates: $16^{\circ}$ 46'79" N latitude, $121^{\circ}$ 23'00.48” E longitude) Cagayan, Philippines.

\section{Seaweeds extraction}

The collected seaweeds were cleaned of epiphytes and extraneous matters, necrotic parts were removed, and finally washed with clean salt water. The epiphytes collected were separated and were tested for antibacterial activity. The seaweeds were air dried at room temperature for two weeks, cut into a small portions were powdered using a hammer mill. Extract of powdered seaweeds were prepared using sequential extraction with different organic solvents in order to increasing the polarity (Ethanolic, n-hexane, dichloromethane and ethyl acetate) by soaking the powder trice in the respective solvents. Each of the pooled extract were filtered and concentrated under vacuum on a rotary evaporator at low temperature to get the crude extracts from each solvent used and reflux method.

\section{Crude extraction with ethanol}

Ethanol was added to the pulverized seaweeds. After 48 hours of soaking, the samples were filtered using a Buchner funnel and flask connected to a vacuum source. A fresh solvent will again be introduces into the sample and were soaked for another 24 hours. These parts were done twice. The collected crude Ethanol extract from these three soaking were concentrated using rotary evaporator under reduce pressure at $45^{\circ} \mathrm{C}$ and reflux method. 


\section{Extraction with n-hexane}

The aqueousfraction obtained after the extraction with ethanol were subjected to liquid-liquid extraction with $50 \mathrm{ml}$-hexane (Malingkrodt) three times. The hexane fraction obtained after the extraction were concentrated using the rotary evaporator under reduced pressure at $45{ }^{\circ} \mathrm{C}$ reflux method.

\section{Extraction with dichloromethane}

The aqueous fraction obtained after the extraction with $\mathrm{n}$-hexane was subjected to liquid-liquid extraction with $50 \mathrm{ml}$ dichloromethane (DCM, Reidel-de Haen) each three times. The DCM fraction obtained after the extraction were concentrated using the rotary evaporator under reduced pressure at $45{ }^{\circ} \mathrm{C}$ reflux method.

\section{Extraction with ethyl acetate}

The aqueous fraction obtained after the extraction with DCM was subjected to liquidliquid extraction with $50 \mathrm{ml}$ ethyl acetate (DCM, each three times. The ethyl acetate fraction obtained after the extraction will be concentrated using the rotary evaporator under reduced pressure at $45{ }^{\circ} \mathrm{C}$ reflux method. Aqueous extract was obtained after the extraction to ethyl acetate.

\section{Bacterial and fungal pathogens}

For testing the antibacterial activity, the following Gram positive; Staphylococcus aureus (BIOTECH 1582), Streptococcus mutans (BIOTECH 10231), Micrococcus luteus (BIOTECH 1061) and Bacillus subtilis (BIOTECH 1679) and Gram negative; Aeromonas hydrophila (BIOTECH 10089), Escherichia coli (BIOTECH 1634), Psuedomonas aeroginosa (BIOTECH 1335) and Psuedomonas flourescens (BIOTECH 1123 ) bacteria strain were selected. For fungal activity, the following fungal strains, Aspergillus parasiticus (BIOTECH 3167) Aspergillus niger (BIOTECH 3080) Candida tropicalis (BIOTECH 2085) Penicillium expansum (BIOTECH 3097) and Sacchromyces cerevisiae (BIOTECH 2096) were used for antifungal activity and they were obtained from the National Institute of Molecular Biology and Biotechnology, University of the Philippines, Los Baños College, Laguna 4031, Philippines.

\section{Anti-microbial assay}

The disk diffusion assay was performed according to Ruangpan and Tendencia (2004). Whatman No. I filter paper disk of $6-\mathrm{mm}$ diameter was sterilized by autoclaving for 15 min at $121{ }^{\circ} \mathrm{C}$. The sterile disks were impregnated with the different crude extracts. The bacteria were sub-cultured to Nutrient Agar for $24 \mathrm{~h}$ prior to use. One loop of each test organism was suspended in $5 \mathrm{ml}$ Trypticase Soy Broth solution separately. Mueller-Hinton Agar (MHA) was surface inoculated with the suspension of the respective organism.

The disks impregnated with the crude extracts of the seaweeds were placed on the MHA medium with suitable apace and the plates were incubated at $32{ }^{\circ} \mathrm{C}$ for 24 hours. Chloramphenicol $(500 \mathrm{mg} / \mathrm{ml})$ was used as a positive and respective solvents were used as a negative control.

The above procedure is allowed for fungal assays, the Saboraud Dextrose Agar (SDA) media were used (Ainsworth, 1971), and the penicillin $(500 \mathrm{mg} / \mathrm{ml})$ was used as a standard and the solvents of each extract as a negative control. The diameter of the growth inhibition halos caused by the different extracts of the seaweeds was measured. The antibacterial assay was carried out in triplicate. 


\section{Data analysis}

The experiments have been repeated 3 times. All data were expressed as mean values $\pm \mathrm{SD}$, the mean values being analyzed using Microsoft Excel 2010 software.

\section{Results and Discussion}

The antimicrobial activity of four (4) species of Sargassum belonging (Paeophyceae) such as Sargassum polycystum, Sargassum oligocystum, Sargassum crassifolium and Sargassum cristaefolium using six (6) different solvents were tested against (13) aquaculture pathogenic bacteria and fungi namely: Aeromonas hydrophila, Escherichia coli, Staphylococcus aureus, Pseudomonas aeruginosa, Micrococcus luteus, Bacillus subtilis, Streptococcus mutans, Psuedomonas flourescens, and Aspergillus parasiticus, Aspergillus niger, Candida tropicalis, Penicillium expansum, Sacchromyces cerevisiae were presented in tables 1 and 2 , respectively.

\section{Sargassum polycystum}

All extracts of $S$. polycystum were active against all the tested aquaculture pathogens. The maximum $(26.33 \pm 3.51 \mathrm{~mm})$ inhibition zone was noticed from the ethanolic extracts against $A$. hydrophila followed by dichloromethane, nHexane, ethyl acetate and aqueous extract showed slight activity against all pathogens. Minimum inhibition $(1 \pm 1.73$ $\mathrm{mm}$ ) was observed from the aqueous extract against M. luteus (Fig. 1). For fungal strain, ethanolic extract against $S$. parasiticus $(13.33 \pm 3.06)$ showed high activity and aqueous extract against $S$. cerevisiae $(3 \pm 5.20 \mathrm{~mm})$ showed low activity (Fig. 2).

\section{Sargassum oligocytum}

Like $S$. polycystum, all S. oligocystum were active to all of the tested aquaculture pathogens. The highest inhibition zone $(18.66 \pm 4.16 \mathrm{~mm})$ was observed in ethanolic extract against $E$. coli followed by ethyl acetate, dichloromethane, n-hexane and the lowest inhibition $(5.33 \pm 3.06 \mathrm{~mm})$ in aqueous extract against $S$. mutans. Among the bacterial pathogens A. hydrophila, E. coli, S. aureus and $B$. subtilis were sensitive to all the extracts (Fig. 3). For fungal strains, the highest activity was recorded in ethanolic extract against $A$. niger $(15.66 \pm 3.06 \mathrm{~mm})$, while $n$-hexane and aqueous had a moderate activity against two pathogens such as $S$. cerevisiae and C. tropicalis $(3.33 \pm 5.77 \mathrm{~mm})$, respectively (Fig. 4).

\section{Sargassum cristaefolium}

The maximum inhibition zone $(24.66 \pm 11.06$ $\mathrm{mm})$ was recorded in ethanolic extracts against A. hydrophila, followed by dichloromethane, n-hexane, ethyl acetate and aqueous extracts showed moderate activity against some bacterial pathogens. Minimum activity $(1 \pm 1.73 \mathrm{~mm})$ was observed in aqueous extract against $P$. aeruginosa (Fig.5). For fungal strain, the maximum inhibition zone was recorded in ethanolic extracts against $A$. niger $(17.33 \pm 3.51 \mathrm{~mm})$. Aqueous had moderate activity against $C$. tropicalis $(2.66 \pm 4.62 \mathrm{~mm})$. Among the solvents ethanolic, dichloromethane, n-hexane, ethyl acetate extracts sensitive to all the pathogens (Fig. 6).

\section{Sargassum crassifolium}

The highest inhibition zone was recorded in ethanolic extract against $A$. hydrophila $(24.33 \pm 0.58 \mathrm{~mm})$. A moderate activity was also seen in ethyl acetate and aqueous extracts against $S$. mutans, E. coli, and B. subtilis (6.33 $\pm 2.08 \mathrm{~mm}, 6.33 \pm 0.58)$. Dichloromethane and n-hexane had different activity against some pathogens (Fig. 7). 
Table.1 Antibacterial activity of Sargassum sp. against aquaculture pathogens

\begin{tabular}{|c|c|c|c|c|c|}
\hline Bacterial Pathogens & Solvent tested & $\begin{array}{l}\text { Sargassum } \\
\text { polycystum }\end{array}$ & $\begin{array}{l}\text { Sargassum } \\
\text { oligocytum }\end{array}$ & $\begin{array}{l}\text { Sargassum } \\
\text { cristaefolium }\end{array}$ & $\begin{array}{l}\text { Sargassum } \\
\text { crassifolium }\end{array}$ \\
\hline \multirow[t]{6}{*}{ Aeromonas hydrophila } & Ethanolic & $26.33 \pm 3.51$ & $17 \pm 5.57$ & $24.66 \pm 11.06$ & $24.33 \pm 0.58$ \\
\hline & nHexane & $11.33 \pm 3.06$ & $9.33 \pm 1.15$ & $15.33 \pm 3.21$ & $14 \pm 4.36$ \\
\hline & Dichloromethane & $12.67 \pm 1.53$ & $8.66 \pm 0.58$ & $21 \pm 11$ & $21.66 \pm 3.06$ \\
\hline & Ethyl acetate & $7 \pm 1$ & $10 \pm 1.15$ & $6.67 \pm 0.58$ & $12 \pm 1.73$ \\
\hline & Aqueous & $3.66 \pm 6.35$ & $7 \pm 4.58$ & $2.66 \pm 4.62$ & $10.66 \pm 1.53$ \\
\hline & Chloramphenicol & $29 \pm 2.65$ & $25.33 \pm 3.06$ & $30.67 \pm 1.53$ & $22.33 \pm 1.15$ \\
\hline \multirow[t]{6}{*}{ Escherichia coli } & Ethanolic & $19.33 \pm 0.58$ & $18.66 \pm 4.16$ & $8.33 \pm 2.52$ & $7 \pm 0$ \\
\hline & nHexane & $17.67 \pm 1.53$ & $6.33 \pm 0.58$ & $14 \pm 1.73$ & $6.33 \pm 0.58$ \\
\hline & Dichloromethane & $17 \pm 1.73$ & $7.33 \pm 0.58$ & $9.33 \pm 1.53$ & $7 \pm 1$ \\
\hline & Ethyl acetate & $13.33 \pm 2.08$ & $8.66 \pm 1.15$ & $10 \pm 3.61$ & $7 \pm 1$ \\
\hline & Aqueous & $3.33 \pm 5.77$ & $6.33 \pm 1.15$ & $2.33 \pm 4.04$ & $6.33 \pm 0.58$ \\
\hline & Chloramphenicol & $33 \pm 1.73$ & $12 \pm 1$ & $33.33 \pm 3.21$ & $12.66 \pm 1.15$ \\
\hline \multirow[t]{6}{*}{ Staphylococcus aureus } & Ethanolic & $14.67 \pm 5.03$ & $11.66 \pm 1.15$ & $10 \pm 4.36$ & $15.33 \pm 2.31$ \\
\hline & nHexane & $18.67 \pm 3.06$ & $14.66 \pm 4.04$ & $7.33 \pm 1.53$ & $14.33 \pm 0.58$ \\
\hline & Dichloromethane & $16.67 \pm 2.52$ & $10 \pm 2$ & $10.67 \pm 0.58$ & $13.33 \pm 1.53$ \\
\hline & Ethyl acetate & $17 \pm 3$ & $10 \pm 1.73$ & $8 \pm 1$ & $13.67 \pm 1.53$ \\
\hline & Aqueous & $4 \pm 6.93$ & $6.33 \pm 4.51$ & - & $7.67 \pm 1.15$ \\
\hline & Chloramphenicol & $32 \pm 1.73$ & $22.66 \pm 17.93$ & $32.33 \pm 1.53$ & $34 \pm 2$ \\
\hline Pseudomonas & Ethanolic & $9.66 \pm 3.05$ & $8.66 \pm 0.58$ & $9.66 \pm 3.51$ & $23.33 \pm 2.08$ \\
\hline \multirow[t]{5}{*}{ aeroginosa } & nHexane & $7 \pm 1$ & $9.33 \pm 0.58$ & $6 \pm 0$ & $21.66 \pm 1.15$ \\
\hline & Dichloromethane & $10.33 \pm 1.53$ & $7.33 \pm 0.58$ & $6 \pm 0$ & $21 \pm 1$ \\
\hline & Ethyl acetate & $8 \pm 1$ & $11.33 \pm 3.06$ & $6 \pm 0$ & $14.33 \pm 2.31$ \\
\hline & Aqueous & $1.33 \pm 2.31$ & $6.66 \pm 2.08$ & $1 \pm 1.73$ & $10.33 \pm 3.21$ \\
\hline & Chloramphenicol & $11 \pm 1$ & $26.33 \pm 2.08$ & $16.66 \pm 6.35$ & $33 \pm 1.73$ \\
\hline \multirow[t]{5}{*}{ Micrococcus luteus } & Ethanolic & $10.33 \pm 0.57$ & $8.33 \pm 1.53$ & $23 \pm 6.08$ & $8.33 \pm 0.58$ \\
\hline & nHexane & $7 \pm 9$ & $16.33 \pm 5.51$ & $7.67 \pm 1.53$ & $9.67 \pm 2.08$ \\
\hline & Dichloromethane & $10.33 \pm 0.58$ & $12.33 \pm 6.66$ & $19 \pm 11.14$ & $11 \pm 2.65$ \\
\hline & Ethyl acetate & $8 \pm 1$ & $10.33 \pm 1.15$ & $6.33 \pm 0.58$ & $15 \pm 1.73$ \\
\hline & Aqueous & $1 \pm 1.73$ & $5.66 \pm 5.03$ & - & $7 \pm 1.73$ \\
\hline
\end{tabular}




\begin{tabular}{|c|c|c|c|c|c|}
\hline & Chloramphenicol & $11 \pm 0.58$ & $33.33 \pm 8.74$ & $30.67 \pm 0.58$ & $30.67 \pm 1.53$ \\
\hline \multirow[t]{6}{*}{ Bacillus subtilis } & Ethanolic & $24.67 \pm 5.69$ & $8 \pm 0$ & $10.66 \pm 3.06$ & $22.67 \pm 1.15$ \\
\hline & nHexane & $15 \pm 3.61$ & $7 \pm 1$ & $9.67 \pm 1.15$ & $15.33 \pm 1.53$ \\
\hline & Dichloromethane & $11.67 \pm 1.53$ & $6.66 \pm 0.58$ & $9.67 \pm 0.58$ & $13.33 \pm 1.15$ \\
\hline & Ethyl acetate & $10.33 \pm 0.58$ & $7.66 \pm 1.53$ & $6 \pm 0$ & $18 \pm 1.73$ \\
\hline & Aqueous & $2.33 \pm 4.04$ & $6.66 \pm 0.58$ & - & $6.33 \pm 0.58$ \\
\hline & Chloramphenicol & $23.33 \pm 4.16$ & $31 \pm 2.65$ & $37.33 \pm 3.21$ & $35.33 \pm 4.93$ \\
\hline \multirow[t]{6}{*}{ Streptococcus mutans } & Ethanolic & $11.66 \pm 3.79$ & $14 \pm 2$ & $21.33 \pm 1.53$ & $8.66 \pm 2.52$ \\
\hline & nHexane & $7 \pm 1$ & $8.33 \pm 2.52$ & $8.66 \pm 0.58$ & $8 \pm 3.46$ \\
\hline & Dichloromethane & $7.66 \pm 1.53$ & $7 \pm 1$ & $18.66 \pm 4.93$ & $7 \pm 1$ \\
\hline & Ethyl acetate & $6.33 \pm 0.58$ & $8.33 \pm 0.58$ & $6 \pm 0$ & $6.33 \pm 2.08$ \\
\hline & Aqueous & $3.66 \pm 0.58$ & $5.33 \pm 3.06$ & $1.33 \pm 2.31$ & - \\
\hline & Chloramphenicol & $24.33 \pm 3.21$ & $28.66 \pm 1.15$ & $33.33 \pm 3.21$ & $32 \pm 2.65$ \\
\hline \multirow{6}{*}{ Psuedomonasflourescens } & Ethanolic & $18.33 \pm 2.89$ & $12 \pm 4$ & $17.33 \pm 2.89$ & $9 \pm 1$ \\
\hline & nHexane & $8.66 \pm 0.58$ & $8 \pm 2$ & $7.66 \pm 2.89$ & $13 \pm 4.58$ \\
\hline & Dichloromethane & $8.33 \pm 1.15$ & $9 \pm 3.46$ & $6.33 \pm 0.58$ & $12 \pm 2$ \\
\hline & Ethyl acetate & $10.66 \pm 0.58$ & $7.66 \pm 1.53$ & $7.66 \pm 0.58$ & $7.33 \pm 1.15$ \\
\hline & Aqueous & $5.3 \pm 0.58$ & $6.66 \pm 3.79$ & $1.66 \pm 2.89$ & - \\
\hline & Chloramphenicol & $28 \pm 1$ & $29 \pm 2.65$ & $30.66 \pm 1.53$ & $30.33 \pm 2.08$ \\
\hline
\end{tabular}

Values are means of three replicate determinations \pm SD, -: No acivity. 
Table.2 Antifungal activity of Sargassum sp. against aquaculture pathogens

\begin{tabular}{|c|c|c|c|c|c|}
\hline Fungal Pathogens & Solvent tested & Sargassum polycystum & Sargassum oligocytum & Sargassum cristaefolium & Sargassum crassifolium \\
\hline \multirow[t]{6}{*}{ Aspergillusparasiticus } & Ethanolic & $13.33 \pm 3.06$ & $15.33 \pm 4.04$ & $12.33 \pm 2.52$ & $12.33 \pm 4.16$ \\
\hline & nHexane & $10.33 \pm 2.52$ & $5.33 \pm 4.62$ & $11 \pm 3$ & $6 \pm 5.20$ \\
\hline & Dichloromethane & $8.66 \pm 0.58$ & $9.66 \pm 2.89$ & $9.6 \pm 2.08$ & $8.66 \pm 0.58$ \\
\hline & Ethyl acetate & $10.66 \pm 2.08$ & $3.66 \pm 6.35$ & $8 \pm 7.21$ & $7 \pm 6.56$ \\
\hline & Aqueous & $7 \pm 6.56$ & $5.67 \pm 4.93$ & $3.66 \pm 6.35$ & $9 \pm 1$ \\
\hline & Penicillin & $17.66 \pm 2.52$ & $17 \pm 6.08$ & $20.33 \pm 2.52$ & $17 \pm 5.20$ \\
\hline \multirow[t]{6}{*}{ Aspergillusniger } & Ethanolic & $12.66 \pm 2.89$ & $15.66 \pm 3.06$ & $17.33 \pm 3.51$ & $16.33 \pm 4.16$ \\
\hline & nHexane & $11 \pm 2$ & $11.33 \pm 4.16$ & $10.66 \pm 2.08$ & $11.33 \pm 3.51$ \\
\hline & Dichloromethane & $8 \pm 7.55$ & $10.66 \pm 3.06$ & $9 \pm 1$ & $10.66 \pm 2.52$ \\
\hline & Ethyl acetate & $6.66 \pm 6.11$ & $12 \pm 3.61$ & $10.66 \pm 2.52$ & $11 \pm 2.65$ \\
\hline & Aqueous & $4.66 \pm 8.08$ & $7.0 \pm 6.56$ & $7.51 \pm 3.21$ & $3 \pm 5.20$ \\
\hline & Penicillin & $20.33 \pm 2.52$ & $23.67 \pm 4.04$ & $20 \pm 2$ & $19.33 \pm 1.53$ \\
\hline \multirow[t]{6}{*}{ Candida tropicalis } & Ethanolic & $12 \pm 2.65$ & $10 \pm 3.46$ & $9.66 \pm 2.08$ & $12 \pm 5.20$ \\
\hline & nHexane & $10.66 \pm 3.06$ & $2.66 \pm 4.62$ & $11.33 \pm 2.52$ & $7 \pm 6.56$ \\
\hline & Dichloromethane & $9.33 \pm 2.31$ & $9 \pm 1.73$ & $9.33 \pm 0.58$ & $9.66 \pm 2.08$ \\
\hline & Ethyl acetate & $10.66 \pm 3.06$ & $2.66 \pm 4.62$ & $6.66 \pm 6.11$ & $6.66 \pm 5.86$ \\
\hline & Aqueous & $3.33 \pm 5.77$ & $3.33 \pm 5.77$ & $2.66 \pm 4.62$ & $5.33 \pm 4.62$ \\
\hline & Penicillin & $16.66 \pm 4.16$ & $18.33 \pm 0.58$ & $18.33 \pm 0.58$ & $18.67 \pm 0.58$ \\
\hline \multirow[t]{6}{*}{ Penicilliumexpansum } & Ethanolic & $12.33 \pm 2.52$ & $12 \pm 5.29$ & $13.33 \pm 4.93$ & $13.66 \pm 3.51$ \\
\hline & nHexane & $6.33 \pm 5.69$ & $11.66 \pm 2.31$ & $11 \pm 2.65$ & $11 \pm 2.65$ \\
\hline & Dichloromethane & $10.66 \pm 2.08$ & $9.33 \pm 1.53$ & $8.33 \pm 8.02$ & $11.33 \pm 2.52$ \\
\hline & Ethyl acetate & $3.66 \pm 6.35$ & $7.33 \pm 7.02$ & $4.66 \pm 8.08$ & $7.66 \pm 7.51$ \\
\hline & Aqueous & $6.33 \pm 5.69$ & $2.67 \pm 4.62$ & $4.33 \pm 7.51$ & $2.66 \pm 4.62$ \\
\hline & Penicillin & $17 \pm 6.56$ & $17.67 \pm 7.09$ & $18 \pm 2$ & $18 \pm 6.24$ \\
\hline \multirow[t]{6}{*}{ Sacchromycescerevisiae } & Ethanolic & $10.66 \pm 3.79$ & $9.33 \pm 1.15$ & $7.66 \pm 7.09$ & $7.66 \pm 6.81$ \\
\hline & nHexane & $3.33 \pm 5.77$ & $3.33 \pm 5.77$ & $6.66 \pm 5.86$ & $6.66 \pm 5.86$ \\
\hline & Dichloromethane & $10.33 \pm 2.31$ & $4.66 \pm 8.08$ & $8.33 \pm 0.58$ & $6.33 \pm 5.51$ \\
\hline & Ethyl acetate & $8.33 \pm 0.58$ & $8 \pm 0$ & $7 \pm 6.56$ & $6.66 \pm 5.86$ \\
\hline & Aqueous & $4.66 \pm 8.08$ & $3.0 \pm 5.20$ & - & $3 \pm 5.20$ \\
\hline & Penicillin & $19.33 \pm 6.11$ & $19.0 \pm 0.58$ & $20.33 \pm 2.52$ & $21.33 \pm 2.31$ \\
\hline
\end{tabular}

Values are means of three replicate determinations \pm SD, -: No acivity 
Figure.1 Zone of inhibition (mm) of the test bacteria against various extracts of Sargassum polycystum. Each bar represents mean values with standard deviation

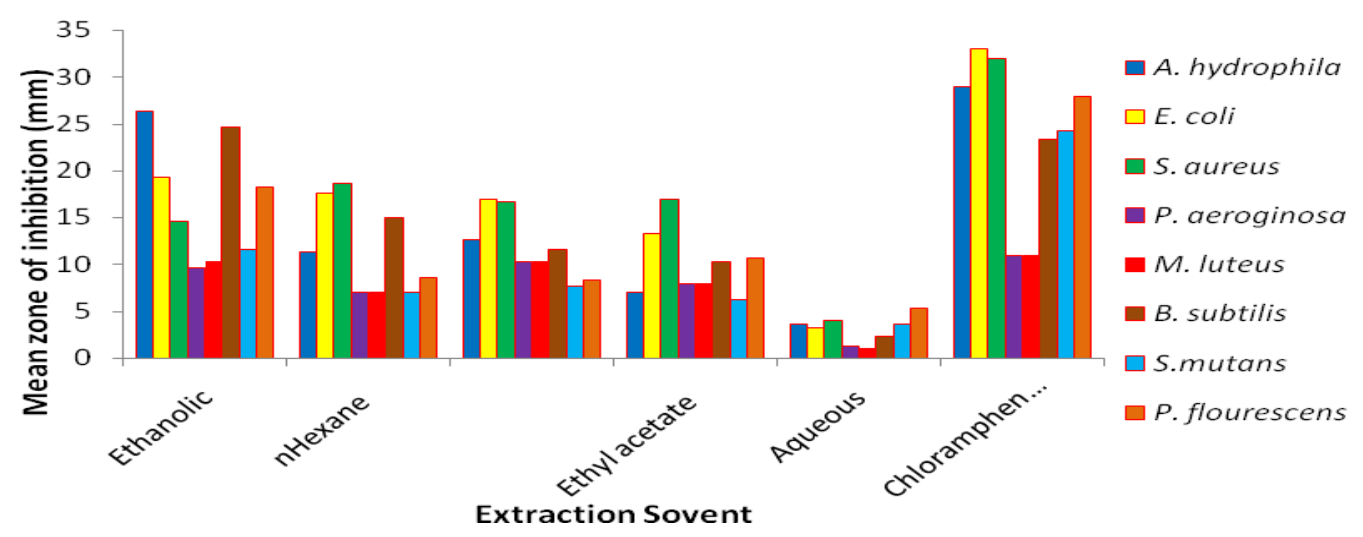

Figure.2 Zone of inhibition ( $\mathrm{mm}$ ) of the test bacteria against various extracts of Sargassum polycystum. Each bar represents mean values with standard deviation

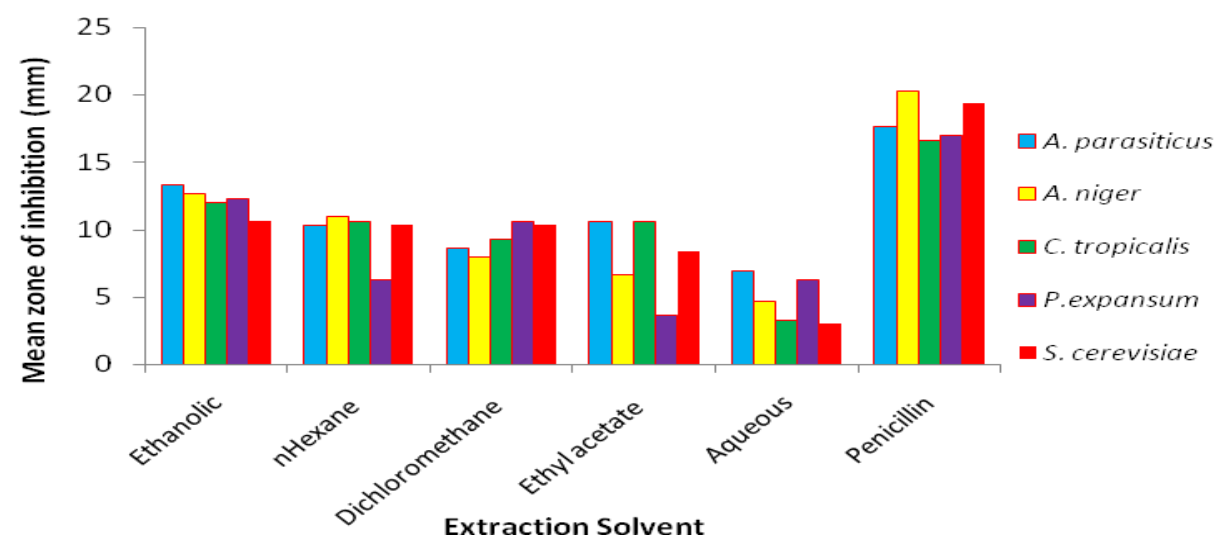

Figure.3 Zone of inhibition ( $\mathrm{mm}$ ) of the test bacteria against various extracts of Sargassum oligocystum. Each bar represents mean values with standard deviation

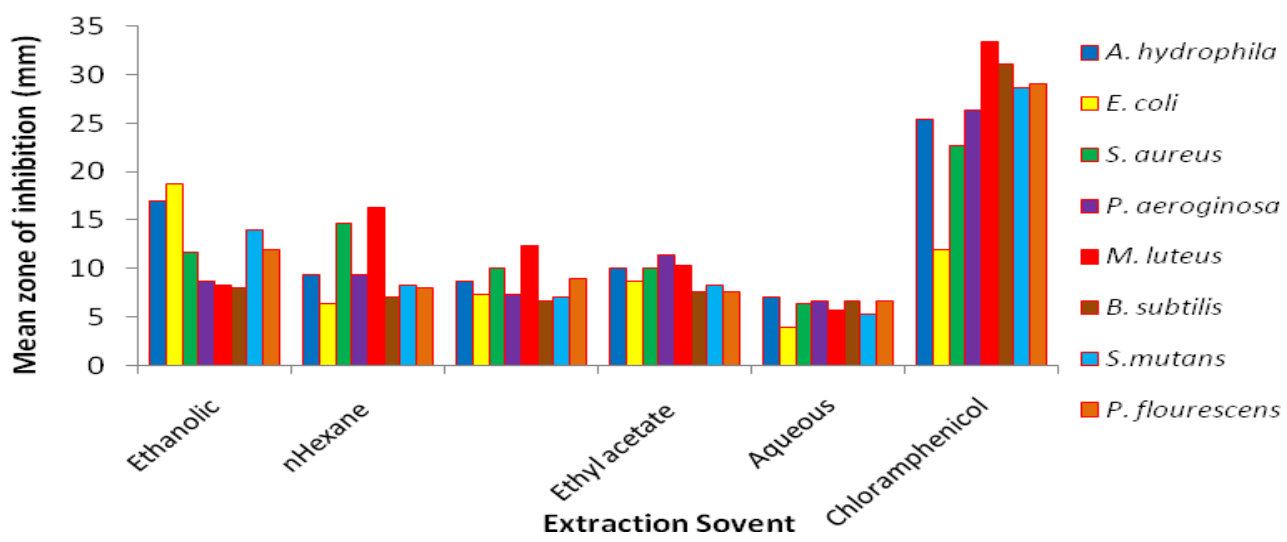


Figure.4 Zone of inhibition (mm) of the test fungi against various extracts of Sargassum oligocystum. Each bar represents mean values with standard deviation

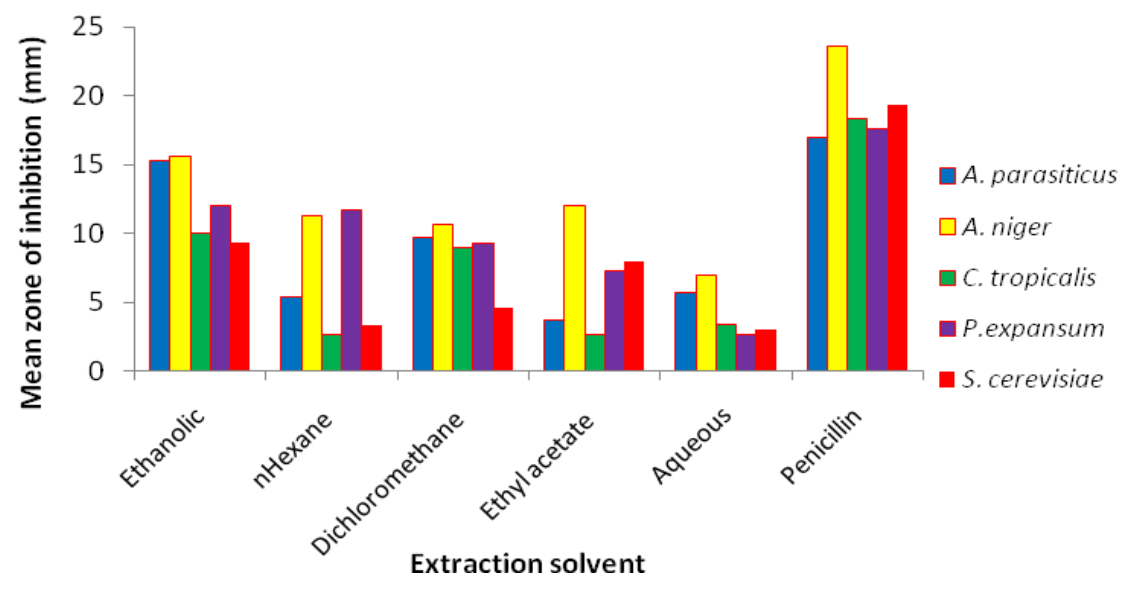

Figure.5 Zone of inhibition (mm) of the test bacteria against various extracts of Sargassum cristaefolium. Each bar represents mean values with standard deviation

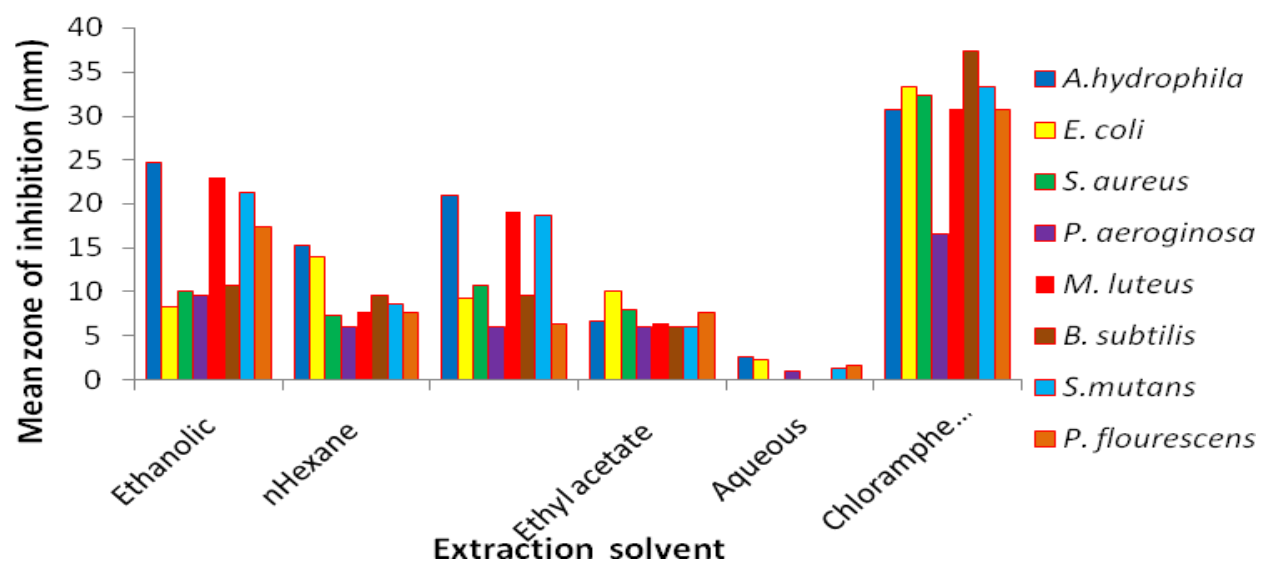

Figure.6 Zone of inhibition (mm) of the test fungi against various extracts of Sargassum cristaefolium. Each bar represents mean values with standard deviation

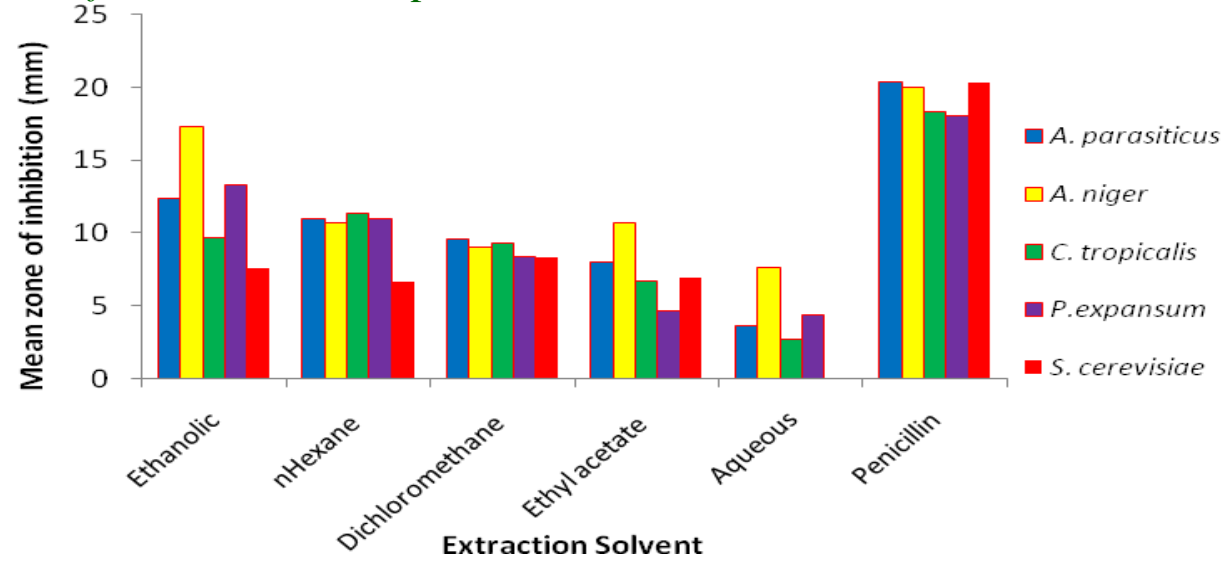


Figure.7 Zone of inhibition (mm) of the test bacteria against various extracts of Sargassum crassifolium. Each bar represents mean values with standard deviation

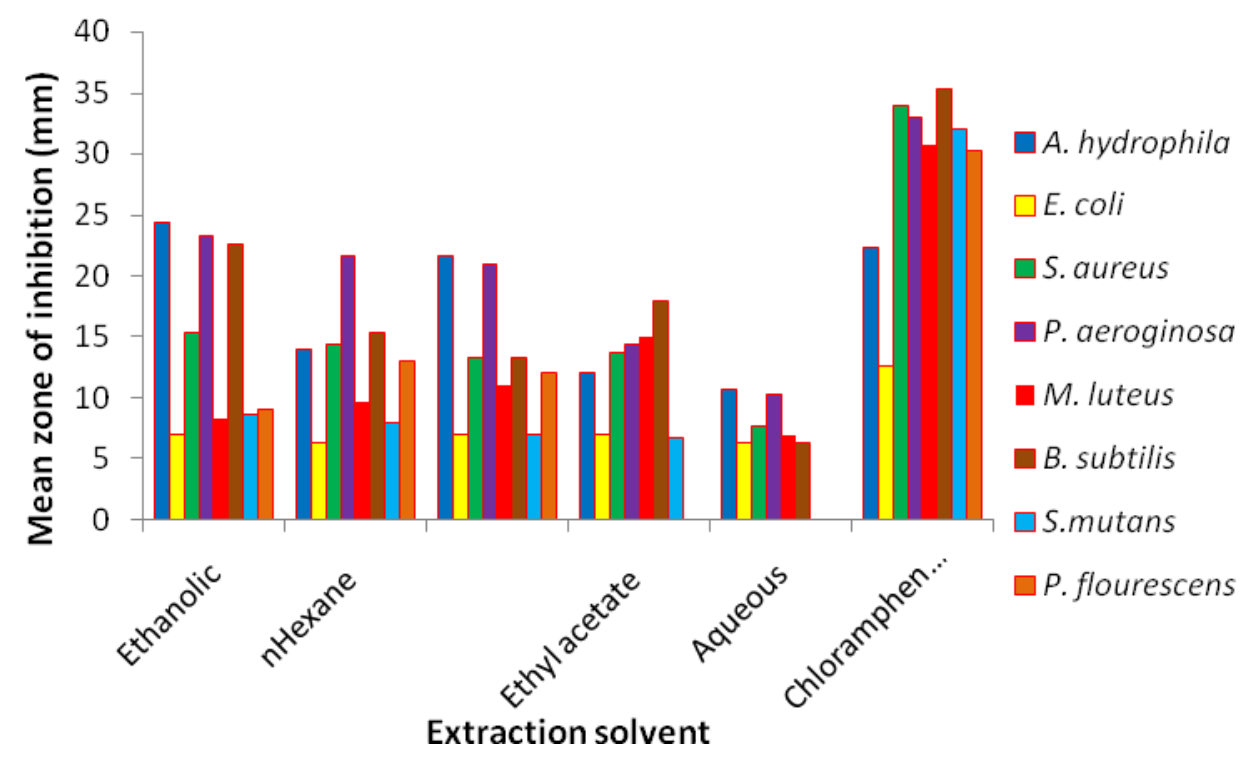

Figure.8 Zone of inhibition (mm) of the test fungi against various extracts of Sargassum crassifolium. Each bar represents mean values with standard deviation

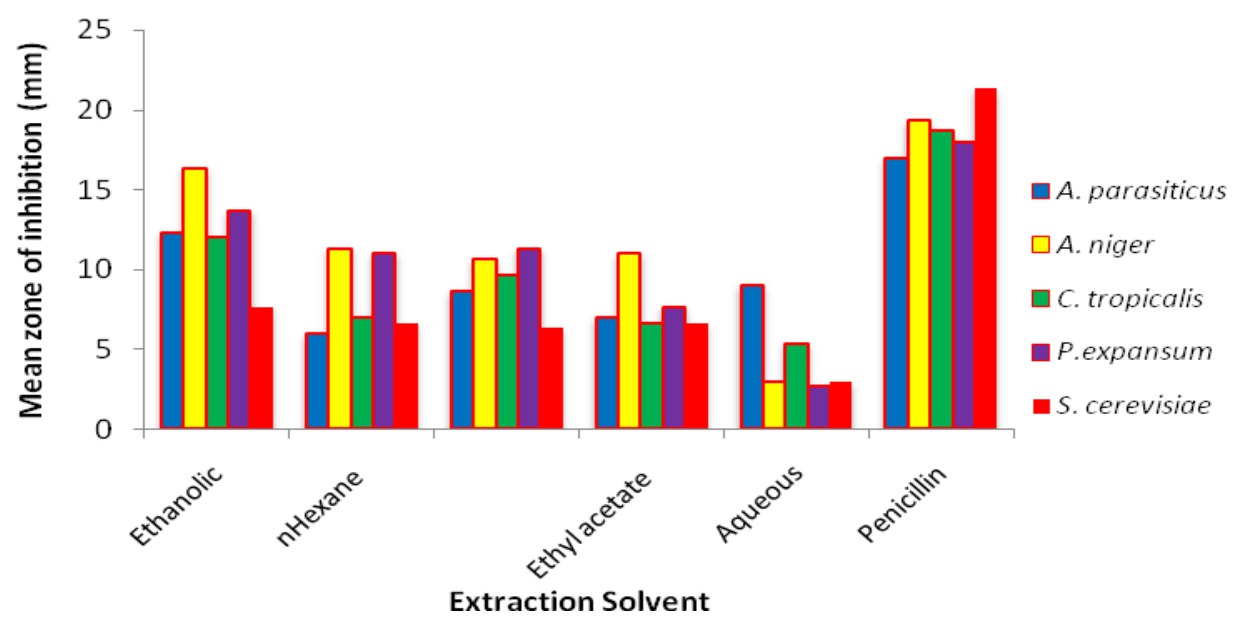

For fungal strain, the maximum inhibition zone was recorded in ethanolic extract against A. niger $(16.33 \pm 4.16 \mathrm{~mm})$ followed by aqueous extracts against $A$. niger and $S$. cerevisiae $(3 \pm 5.20 \mathrm{~mm})$ showed moderate activity (Fig. 8). The continuous use of antimicrobial agents in aquaculture has resulted in accumulation of more resistant bacterial strains in aquatic environment and may also create threats to consumers (Muniruzzaman and Chowdhury, 2004). Since ancient times, marine plants extracts have been used for treatments of common infectious diseases, treatments with plants having antibacterial activity are a potential beneficial alternative in aquaculture (Abutbul 
et al., 2005). Several works have been undertaken on crude and purified compounds obtained from seaweeds for evaluating their bioactive potential. Phaeophyceae were the most active in comparison with chlorophyceae (Oumaskour et al., 2012) and rhodophyceae (Caccamese et al., 1985). These strong activities related to brown algae may be due to the phenolic compounds such as phlorotannins, eckol and eckol- related compounds that have strong bactericidal activity (Nagayama et al., 2002).

The results from the present study revealed that the n-hexane, dichloromethane, ethyl acetate extracts displayed different antimicrobial activity against different aquaculture pathogenic bacteria and fungi whereas ethanolic extracts showed higher antimicrobial activity than aqueous extracts that confirms the previous findings (JeyanthiRebecca et al., 2012; Oumaskour et al., 2012). The ethanol extract of Sargassum myricocystum (brown alga) showed a significant antifungal activity against pathogen (Colletotrichum falcatum) followed by Gracilaria edulis(red alga) (Ambika and Sujatha, 2015). Ethanol extracts of Sargassum glaucescensas produced higher antibacterial and anti-fungal activity than chloroform, methanol and n-hexane (Mahianeh et al., 2014).

Several authors concerning the effectiveness of solvent used for extraction the bioactive compounds, reported that the chloroform and ethyl acetate extracts Enteromorpha compressa, Chaetomorphalinum and Polysiphonia subtilissima were active against most of the pathogens whereas methanol and ethanol extracts were active only against Shigella flexneri (Patra et al., 2009). However, in another study by Salem et al., (2011), revealed that the ethyl acetate was to the best solvent for isolation of antimicrobial activity from the tested marine algae followed by methanol which in contrast to our results. This difference in result might be due to the presence of different antibacterial substances among these species as suggested by Lustigman and Brown (1991), and due time and place of sampling collection, capability of extraction protocol to recovered the active metabolites and the assay methods (Salem et al.,2011), Solvents solubility efficiency is strongly dependent on material used for extraction (Zhou and Yu 2004; Grigonisa et al., 2005; Michiels et al., 2012), and antifungal activity of seaweeds depends on the species from different division (Saidani $e t$ al., 2012).

In the present investigation, the crude extracts of tested Sargassum spp. showed a significant antimicrobial activity against Gram-positive and Gram-negative as well as the fungus. Antimicrobial activity of brown seaweeds such as Sargassum polycystum and Sargassum tenerrimum showed significant activity against both gram-positive, gramnegative and fungal pathogens (Kausalya and Narasimha Rao, 2015), which confirms in the present investigation. Seaweeds are an excellent source of components such as polysaccharides, tannins, flavonoids, phenolic acids, bromophenols, and carotenoids has exhibits different biological activities (Bhacuni and Rawat, 2005; Rodriguez et al., 2010; Priyadharshini et al., 2011). In addition, the polyunsaturated esters may be the compound responsible for antimicrobial activity in different Sargassum species (Ambreen, 2012).

In the present study it was noticed that the, Sargasssum polycystum showed better antimicrobial activity among the brown seaweeds tested. This might be due to the presence of higher potential antimicrobial compound found in $S$. polycystum than Sargassum oligocystum, Sargassum crassifolium and Sargassum cristaefoliumas 
indicated in the result. As supported by the study of (Chong et al., 2011) these author showed that the $S$. polycystum had a broader bactericidal spectrum when compared with the $P$. australis and the $S$. polycystum exhibited bactericidal potential on both $S$. aureus and $B$. cereus. In addition, the phenolic contents of $S$. polycystum collected from Malaysia were higher compared with other seven species of seaweeds including Padina sp. (Matanjun et al., 2008). Sargassum sp. and Esiena bicyclis (B36) which showed strong antibacterial activities against Methicillin-resistant Staphylococcus aureus (MRSA) strains, Vibrio parahemolyticus and Edwardsiella tarda (Kim and Lee, 2008). Species of Phaeophyta showed the strongest activities against fungi (Kumar et al., 2014). The brown seaweeds contain high amount of flavanoid and phenolic compound could be the reason for antifungal activity (Cowan et al., 1999).

In conclusion, overall the various crude extracts of Sargassum spp. showed promising activities against the selected aquaculture pathogens. It can observed that the ethanolic, n-Hexane, dichloromethane, ethyl acetate and aqueous extracts showed significantly inhibitory effect against most tested aquaculture pathogens. The results showed that the ethanolic extracts of Sargassum polycystum was better antimicrobial activity among the brown seaweeds tested has potentially used as antimicrobial agent and as natural immunostimulant in aquaculture industry for treated microbial diseases in infected fishes.

\section{Acknowledgement}

This study was funded by a grant from the Department of Agriculture - Bureau of agricultural Research (DA-BAR). We would like to thank the Department of Natural Sciences and Mathematics, College of Arts and Sciences, Isabela State University, Main Campus for providing research facilities for this study.

\section{References}

Abutbul, S., A. Golan-Goldhirsh, O. Barazani, R. Ofir and Zilberg, D. 2005. Screening of desert plants for use against bacterial pathogens in fish. Isr. J. AquacBamidgeh., 57(2): 71-80.

Ainsworth, G.C. 1971. Ainsworth and Bisby"s Dictionary of the fungi. Common wealth Mycological Institute, Kew Surrey England.

Ambika, S. and Sujatha, A. 2015. Antifungal activity of aqueous and ethanol extracts of seaweeds against sugarcane red rot pathogen (Colletotrichumfalcatum). Acad J., 10: 232- 5.

Ambreen, K., Hira, A., Tariq, Ruqqia, V., Sultana and Ara, A. 2012. Evaluation of Biochemical Component and Antimicrobial Activity of Some Seaweeeds Occurring At Karachi Coast. Pak. J. Bot., 44(5): 1799-1803.

Baleta, F.N., L.V. Laureta, M.J.S. ApinesAmar, P.I.P. Padilla and G.F. Quinitio. 2011. Biological Activity of Extract Sargassum oligocystum (Magnaye) against Aquaculture Pathogenic Bacteria. Isr. J. Aquacult.-Bamidgeh, 63: 667-671.

Bhacuni, D.S. and Rawat, D.S. 2005. Bioactive Marine Natural Products. Spinger/ Anamaya Publishers, pp. 400.

Caccamese, S., R.M. Toscana, G. Funari and Cormaci, M. 1985. Antimicrobial and antiviral activities of some marine algae from southern Italy coast. Bot. Mar., 24: 505-507.

Chong, C.W., S.L. Hii and Wong, C.L. 2011. Antibacterial activity of Sargassum polycystum C. Agardh and Padinaaustralis Hauck (Phaeophyceae). African J. Biotechnol., 10(64): 14125- 
14131.

Cowan, M.M. 1999. Plants products as antimicrobial agents, Clin. Microbiol. Rev., 12: 564-582.

Dashtiannasab, A., S. Kakoolaki, M. Sharif Rohani and Yeganeh, V. 2012. In vitro effects of Sargassum latifolium (Agardeh, 1948) against selected bacterial pathogens of shrimp. Iranian J. Fisheries Sci., 11(4): 765-775.

Dawczynski, C., R. Shubertand G. Jahreis. 2007. Amino acids, fatty acids and dietary fibre in edible seaweed products. Food Chem., 103: 891-899.

Grigonisa, D., P.R. Venskutonis, B. Sivikb, M. Sandahlb and Eskilssonc, C.S. 2005. Comparison of different extraction techniques for isolation of antioxidants from sweet grass (Hierochloeodorata). J. Supercritical Fluids, 33: 223-233.

Ireland, C.M., D.M. Roll, T.F. Molinsk, T.C. Mckee, T.M. Zarbriske and Swersey, J.C. 1988. Uniqueness of the marine environment: categories of marine natural product from invertebrates In: D.G. Fautin, (ed.) Biomedical importance of marine organisms. California Academy of Sciences, San Francisco., pp.41-58.

Jeyanthi Rebecca, L., V. Dhanalakshmi and Shekhar, C. 2012. Antibacterial activity of SargassumIlici folium and Kappaphycusalvarezii. J. Chem. Pharmaceutical Res., 4(1): 700-705.

Kausalya, M., and Narasimha Rao, G.M. 2015. Antimicrobial activity of marine algae. J. Algal Biomass Utln., 6(1): 7887.

Kim, I.H., and Lee, J.H. 2008. Antimicrobial activities against methicillin-resistant Staphylococcus aureusfrom macroalgae. J. Ind. Eng. Chem., 14: 568-572.

Kumar, N.J.I., M. Barot and Kumar, R.N. 2014. Phytochemical Analysis and Antifungal Activity of Selected
Seaweeds from Okha Coast, Gujarat, India. Life Sci. Leaflet, 52: 57-70.

Lustigman, B., and Brown, C. 1991. Antibiotic production by marine algae isolated from the New York/New Jersey Coast. Bull. Environ. Contamination and Toxicol., 46: 29-335.

Mahianeh, A., B. Ghaednia, M. Mirbakhsh, M. Velayatzadeh, E. Mohammadi, M. Jafari, E. Kamrani and Ghaedifard, B. 2014. The effects of brown alga, Sargassum glaucescensas (Agardeh, 1948) against selected bacterial, fungal and yeast pathogens of shrimp. Int. J. Biosci., 5(12): 399-405.

Matanjun, P., S. Mohamed, N.M. Mustapha, K. Muhammad and Ming, C.H. 2008. Antioxidant activities and phenolics content of eight species of seaweeds from north. Borneo J. Appl. Phycol., 20: 367-373.

Michiels, J.A., C. Kevers, J. Pincemail, J.O. Defraigne and Dommes, J. 2012. Extraction conditions can greatly influence antioxidant capacity assays in plant food matrices. Food Chem., 130(4): 986-993.

Muniruzzaman, M., and Chowdhury, M.B. 2004. Sensitivity of fish pathogenic bacteria to various medicinal herbs. Bangl. J. Vet. Med., 2(1): 75-82.

Nagayama, K., Y.Iwamura, T.Shibata, I. Hirayama and Nakamura, T. 2002. Bactericidal activity phlorotannins from the brown alga Eckloniakurome. $J$. Antimicrob. Chemother., 50: 889-893.

Newman, D.J., G.M. Cragg and Snader, K.M. 2003. Natural products as source of new drugs over the period 1981-2002, J. Natural Products, 66: 1022-1037.

Oumaskour, K., N. Boujaber, S. Etahiri and Assobhei, O. 2012. Screening of antibacterial and antifungal activities in green and brown algae from the coast of SidiBouzid (El Jadida, Morocco). African J. Biotechnol., 11(104): 16831- 
16837.

Padmakumar, K., and Ayyakkannu, K. 1997. Seasonal variation of antibacterial and antifungal activities of the extracts of marine algae from Southern coasts of India, Botanica Marina, 40: 507-515.

Patra, J.K., A.P. Patra, N.K. Mahapatra, H.N. Thatoi, S. Das, R.K. Sahu and Swain, G.C. 2009. Antimicrobial activity of organic solvent extracts of three marine macroalgae from Chilika Lake, Orissa, India. Malaysian J. Microbiol., 5(2): 128-131.

Priyadharshini, S., S. Bragadeeswaran, K. Prabhu and Ran, S.S. 2011. Antimicrobial activity and hemolytic activity of seaweed extracts Ulvafasciata (Delile 1813) from Mandapam, Southeast coast of India. In Asian Pacific J. Trop. Biomed., 1: S38S39.

Rodriguez-Bernaldo de Quiros, A., M.A. Large-Yusty and Lopez-Hernadez, J. 2010. Determination of phenolic compounds in macroalgae for human consumption. Food Chem., 121: 634638.

Ruangpan, L., and Tendencia, J. 2004. Laboratory Manual of Standardized Methods for Antimicrobial Sensitivity Test for Bacteria Isolation from Aquatic Animals. Southeast Asian Fisheries Development Center (SEAFDEC), 37(2):13-27.

Saidani, K., F. Bedjou, F. Benabdesselam and Touati, N. 2012. Antifungal activity of methanolic extracts of four Algerian marine algae species. African $J$.
Biotechnol., 11(39): 9496-9500.

Salem, W.M., H. Galal, and Nasr El-deen, F. 2011. Screening for antibacterial activities in some marinealgae from the red sea (Hurghada, Egypt). African $J$. Microbiol. Res., 5(15): 2160-2167.

Sanil, N.K., and Vijayan, K.K. 2008. Diseases in ornamental fishes. In: Kurup BM, Boopendranath MR, Ravindran K, Banu S, Nair AG (eds.). Ornamental fish breeding, farming and trade. Thiruvananthapuram: Department of Fisheries., pp. 175-189

Smith, P., M.P. Hiney and Samuelsen, O.B. 1994. Bacterial resistance to antimicrobial agents used in fish farming, Annu. Rev. Fish. Dis., 4: 273313.

Taskin, E., M. Ozturk, E. Taskin and Kurt, O. 2007. Antibacterial activities of some marine algae from the Aegean Sea (Turkey). African J. Biotechnol., 6(24): 2746-2751.

Toney, I., B.H. Cadrici, D. Unal and Suctar, A. 2006. Antimicrobial Activities of the Extracts of Marine Algae from the Coast of Urla (Izmir, Turkey). Turkish J. Biol., 30: 171-175.

Vinayak, R.C., A.S. Sabu and Chatterji, A. 2011. Bio-prospecting of a few brown seaweeds for their cytotoxic and antioxidant activities. Evid Based Complement Alternat. Med., 7: 1-9.

Zhou, K., and Yu, L. 2004. Effects of extraction solvent on wheat bran antioxidant activity estimation, LWT. Food Sci. Technol., 37(7): 717-721.

\section{How to cite this article:}

Jonathan MallillinBolaños, Francis NuestroBaleta and Jayson Domingo Cairel. 2017. Antimicrobial Properties of Sargassum spp. (Phaeophyceae) against Selected Aquaculture pathogens. Int.J.Curr.Microbiol.App.Sci. 6(2): 1024-1037.

doi: http://dx.doi.org/10.20546/ijcmas.2017.602.115 